\title{
Effect of IAA on Morphogenesis of Musa Apices, and IAA Degradation During Storage of Media
}

\author{
Shin Hiratsuka ${ }^{1}$, Jiro Matsushima ${ }^{1}$, \\ Toyoki KozAI ${ }^{2}$ and Ichiro WatanABE ${ }^{2}$ \\ ${ }^{1}$ Faculty of Bioresources, Mie University, Tsu, Mie 514 \\ ${ }^{2}$ Faculty of Horticulture, Chiba University, Matsudo, Chiba 271
}

\begin{abstract}
Summary
IAA (indole-3-acetic acid) added to MS (Murashige and Skoog) medium was quantified by HPLC (high performance liquid chromatography) during storage of the media under various conditions. Illumination $(5,000 \mathrm{~lx})$ of the media with fluorescent white lamps degraded IAA significantly, but temperature treatment $\left(25^{\circ} \mathrm{C}\right)$ under the dark condition had no strong effect on IAA degradation. Under the light conditions $(5,000 \mathrm{~lx})$ at $25^{\circ} \mathrm{C}$ where in vitro rooting and shoot growth of Musa apices were enhanced well by adding IAA, the amount of IAA decreased papidly and almost no IAA was detected 8 days after treatment. The effect of IAA on morphogenesis of Musa apices was clearly observed in the present study. These facts suggest that shoot apices of Musa on the media absorb and use IAA at initial times after inoculation.
\end{abstract}

\section{Introduction}

Usually, auxines have a definite influence on rooting of explants cultured in vitro (8). In micropropagation of Musa, IAA also has an important role in shoot growth and rooting(1). On the other hand, it is known that some plant growth regulators such as IAA, abscisic acid and gibberellins are unstable to high temperature or illumination. In many cases, tissue culture has to be carried out under light and the explants require relatively high temperature. However, the behavior of IAA under tissue culture conditions is not well understood. The present paper reports on IAA degradation in the MS medium, with reference to the effects of IAA on morphogenesis of Musa.

\section{Materials and Methods}

\section{Plant materials}

Banana plants, Musa acuminata Colla, var. Sanjaku banana, were kindly provided by Daijuen, Co. Ltd., Toyohashi, Japan. Preparation of the media and tissue culture

IAA was first dissolved with $0.1 \mathrm{~N} \mathrm{NaOH}$ and adjusted at $\mathrm{pH} 5.7$ with $0.1 \mathrm{~N} \mathrm{HCl}$. The IAA solution was then added to the autoclaved

\footnotetext{
Received for publication June 29, 1987.
}

medium ( $\mathrm{pH} 5.7$ ) kept at about $60{ }^{\circ} \mathrm{C}$, through a milliporefilter $(0.45 \mu \mathrm{m}$, Millipore Corporation Co. Ltd., Massachusetts) under sterile conditions. BA dissolved in $0.1 \mathrm{~N} \mathrm{NaOH}$ was added to the medium and adjusted to $\mathrm{pH} 5.7$ with $0.1 \mathrm{~N} \mathrm{HCl}$ before autoclaving. Glass tubes with alminum-foil caps containing about $10 \mathrm{~m} l$ of medium were employed in all experiments. Shoot apices were excised on a clean bench and planted on solid MS(Murashige and Skoog) (7) media containing $30 \mathrm{~g} / l$ sucrose and $8 \mathrm{~g} / l$ agar supplemented with $3 \mathrm{mg} / l \mathrm{BA}$ or $1 \mathrm{mg} / l$ IAA or $3 \mathrm{mg} / l \mathrm{BA}$ plus $1 \mathrm{mg} / l$ IAA. They were cultured at $25^{\circ} \mathrm{C}$ under continuous light of 5,000 lx supplied with white fluorescent lamps. Shoot length, number of shoots, root length and number of roots were recorded weekly.

Illumination and temperature treatments of the media

The glass tubes containing about $10 \mathrm{ml}$ of MS media with $1 \mathrm{mg} / l$ IAA were placed under following conditons; light $(5,000 \mathrm{~lx}): 25^{\circ} \mathrm{C}$, dark : $25^{\circ} \mathrm{C}$, light : $4{ }^{\circ} \mathrm{C}$, dark : $4{ }^{\circ} \mathrm{C}$ and dark : $-20^{\circ} \mathrm{C}$. Explants were not inoculated in these tubes.

Extraction and purification of IAA

Five grams of each treated medium were 
sampled and IAA was extracted with $25 \mathrm{~m} l$ of ethanol overnight. Then, they were filtrated through filtration paper (Toyo No. 2) and the residue washed with $5 \mathrm{ml}$ of ethanol 3 times. The combined filtrate was evaporated in vacuo to water phase, adjusted at $\mathrm{pH} 3.0$ with $\mathrm{HCl}$ and passed through Sep-pack C18 cartridge (Waters, Co. Ltd., Massachusetts) 2 times. The cartridge was equilibrated previously at $\mathrm{pH} 3.0$ with $\mathrm{CH}_{3} \mathrm{COOH}$. The IAA in the cartridge was eluted with $5 \mathrm{ml}$ of ethyl acetate(EtOAC) 2 times, evaporated in vacuo to dryness and redissolved with $\mathrm{EtOH}$. The solution was passed through milliporefilter (Nihon Millipore Kogyo, Co. Ltd., Japan) to remove the precipitates, evaporated again to dryness and dissolved with $100 \mu \mathrm{l}$ of $\mathrm{EtOH}$. Twenty microliters of the solution were subjected to HPLC analysis. All operations were carried out below $40^{\circ} \mathrm{C}$. Samples were kept from light as far as possible

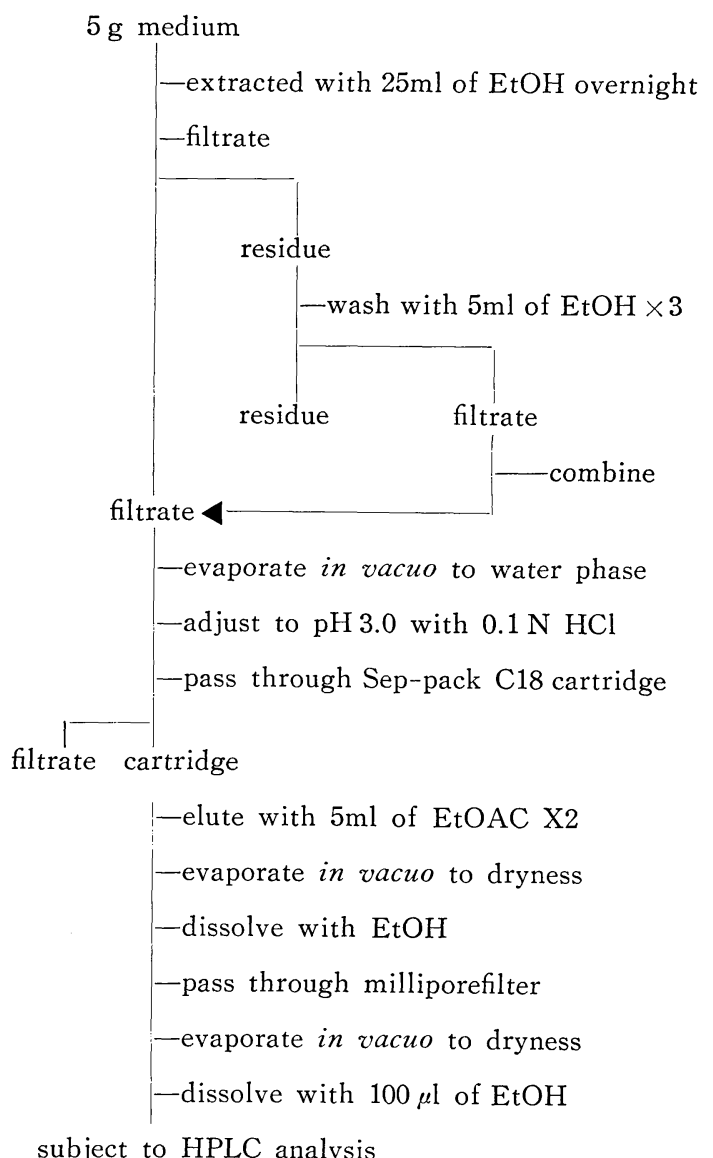

subject to HPLC analysis

Fig. 1. Extraction and purification procedure of IAA from MS medium. during these operations. The procedures are summarized in Fig. 1. Although the sampling was performed at intervals of 3 weeks in the preliminary experiments, almost no IAA was detected 3 weeks later under light conditions. Therefore, the media were sampled at intervals of 3 days.

HPLC analysis of IAA

HPLC (Hitachi, 655A-12) equipped with ODS column (Hitachi YMC pack, A-302, 150 $\mathrm{mm}$ in length $\times 4.6 \mathrm{~mm}$ in width) and a UV detector was used. An ethanol gradient system, from 50 to $100 \%$, was employed and flow rate was $0.2 \mathrm{ml} / \mathrm{min}$. Under these conditions, the retention time of IAA was about $21 \mathrm{~min}$ (Fig. 2). Peak heights rather than peak areas in the elution profiles of IAA compared well with the amounts of standard IAA injected. Therefore, the amounts of IAA were calculated by their peak heights. The calculation formula was : $y=0.0559 x+9.4095, y:$ the amount of IAA (ng), $x$ : peak height. Experiments were duplicated and mean values are shown.

\section{Results and Discussion}

Fig. 3 shows the growth of shoots generated from Musa apices with IAA and/or BA. Shoot growth was promoted by adding IAA to the

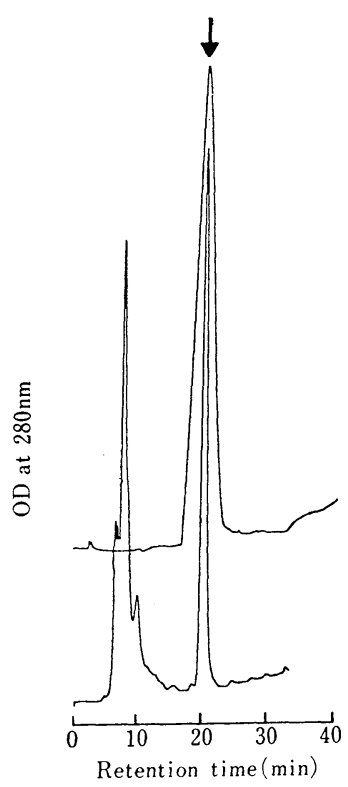

Fig. 2 Elution profiles of IAA. Upper: standard IAA $(1 \mu \mathrm{g})$, Lower: IAA extracted from MS medium. Arrow indicates IAA. 
medium. Shoot length was 3 times that with $\mathrm{BA}$ only, 4 weeks after inoculation. In the medium with IAA + BA shoot growth was intermediate between that of the medium with IAA and that with BA. On the other hand, BA stimulated adventitious bud formation of the explants. At 4 weeks after inoculation, the number of shoots per explant was 1.6 with BA,

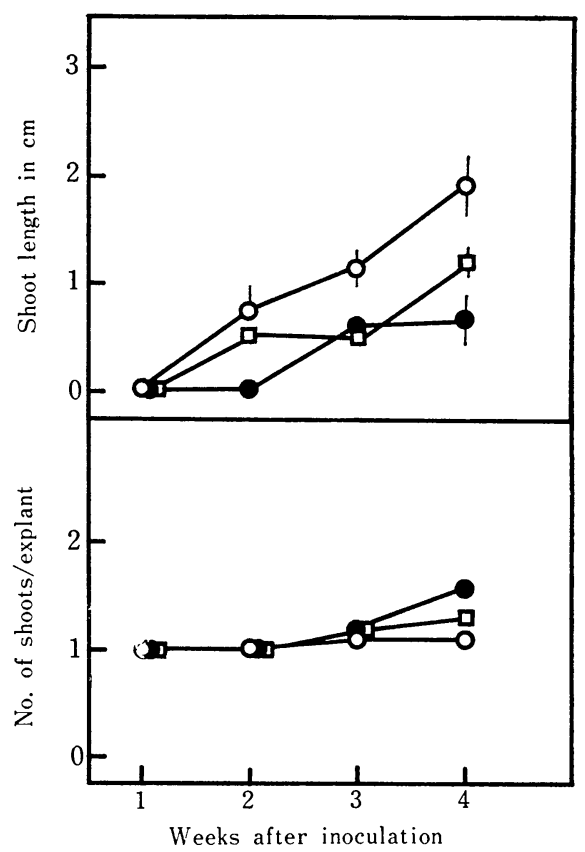

Fig. 3. Effect of IAA and BA on shoot growth (upper)and shoot formation(lower). $0: 3 \mathrm{ppm}$ $\mathrm{BA}, \quad \bigcirc: 1 \mathrm{ppm}$ IAA, $\square: 3 \mathrm{ppm} \quad \mathrm{BA}+1 \mathrm{ppm}$ IAA. Vertical bars indicate SE.

Table 1. Effect of IAA and BA on shoot and root growth.

\begin{tabular}{lccc}
\hline & \multicolumn{3}{c}{2 months after inoculation } \\
\cline { 2 - 4 } & IAA & BA & IAA+BA \\
\cline { 2 - 4 } & $52.3 \pm 7.6$ & $16.6 \pm 1.4$ & $18.9 \pm 3.1$ \\
Shoot length (mm) & 1.2 & 4.3 & 2.7 \\
No. of shoots/explant & $14.6 \pm 1.7$ & $17.0 \pm 1.1$ \\
Root length (mm) & $26.9 \pm 3.1$ & 14.0 & \\
No. of roots/explant & $9.0 \pm 1.0$ & $2.4 \pm 0.4$ & $4.2 \pm 1.5$ \\
\hline & 3 months after inoculation \\
\cline { 2 - 4 } & IAA & BA & IAA+BA \\
\cline { 2 - 4 } & $67.4 \pm 12.3$ & $31.7 \pm 7.1$ & $45.6 \pm 5.4$ \\
Shoot length (mm) & 1.3 & 4.0 & 1.7 \\
No. of shoots/explant & $30.2 \pm 2.1$ & $25.3 \pm 1.5$ & $21.9 \pm 1.9$ \\
Root length (mm) & $30.9 \pm 0.4$ & $12.0 \pm 3.5$ \\
No. of roots/explant & $16.8 \pm 3.4$ & $16.8 \pm 4.0$ &
\end{tabular}

whereas it was 1.1 with IAA. The number of shoots 3 months after inoculation decreased compared with that 2 months later, in both media with $\mathrm{BA}$ and BA+IAA (Table 1 ).

Several shoots seemed to brown at this time in these media.

IAA also had a strong effect on rooting of the Musa explants. The mean number of roots per explant was 4.57 and mean length was 1.15 $\mathrm{cm}$ at 4 weeks after inoculation, whereas no rooting was observed at this time in the medium with BA only (Fig. 4). The effects of IAA on the morphogenesis of Musa apices. especially on root formation, were already observed at 2 weeks after inoculation (Fig. 5-A). Several roots were obseved 2 months later in the media with BA and gradually developed thereafter (Table 1, Fig. 5-B).

In the present study, BA seemed to suppress the effect of IAA on growth of shoots and roots of Musa. Antagonistic effects between auxins and cytokinins on root elongation were also found in Lens. Cytokinin seems to induce auxin oxidase such as peroxidase in the root, resulting in inactivation of auxin(4). On the con-

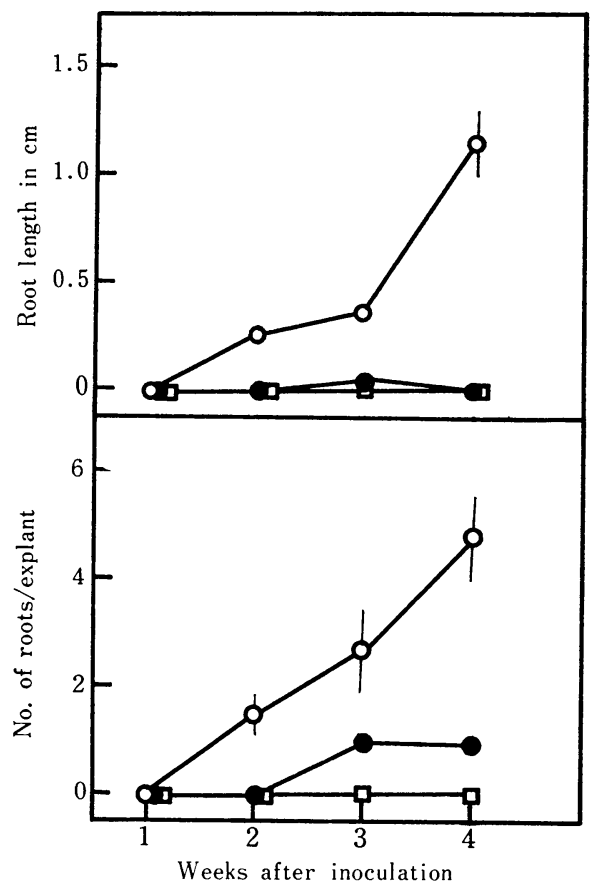

Fig. 4. Effect of IAA and BA on root growth (upper)and root formation (lower). $0: 3 \mathrm{ppm}$ $\mathrm{BA}, \bigcirc: 1 \mathrm{ppm}$ IAA, $\square: 3 \mathrm{ppm} \mathrm{BA}+1 \mathrm{ppm}$ IAA. Vertical bars indicate SE. 


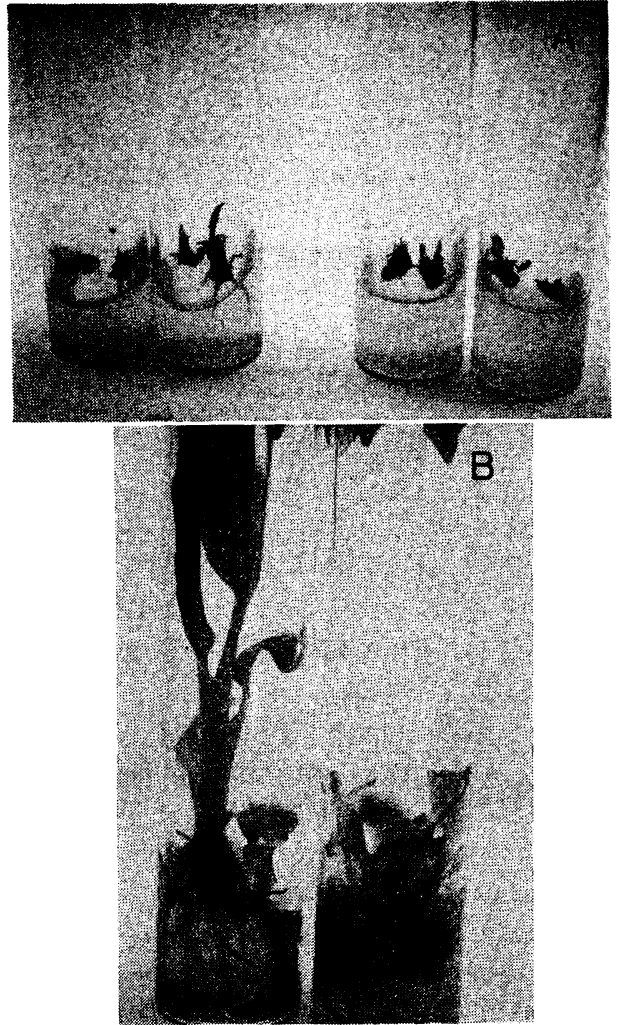

Fig. 5. Shoot apices cultured on MS media. A ; Two weeks after inoculation. Right: 3 ppm BA, Left: 1 ppm IAA. Note the formation of adventitious roots. B; Two months after inoculation. Right: 3 ppm BA, Left: 1 ppm IAA.

rary, auxins alter the metabolism of endogenous cytokinins in bark explants (3) and oat stem segments (5).

Although IAA in the media was rather stable in the dark even at $25^{\circ} \mathrm{C}$ for several weeks, illumination treatments of 5,000 lx degraded IAA significantly (Table 2). Under light, degradation of IAA was more rapid at $25^{\circ} \mathrm{C}$ than at $4{ }^{\circ} \mathrm{C}$. At 8 days after illumination, the amount of IAA reducd by $65 \%$ of the initial

Table 2. Degradation of IAA in MS media subjected to various treatments.

\begin{tabular}{ccrrr}
\hline \hline & \multicolumn{4}{c}{ Treatment period (days) } \\
\cline { 2 - 5 } Treatment & \multicolumn{1}{c}{0} & \multicolumn{1}{c}{4} & \multicolumn{1}{c}{8} & 12 \\
\hline $25^{\circ} \mathrm{C}$ Light & $1055(\mathrm{ng})$ & 356 & 108 & 83 \\
$25^{\circ} \mathrm{C}$ Dark & & 975 & 1147 & 1182 \\
$4{ }^{\circ} \mathrm{C}$ Light & & 876 & 699 & 444 \\
$4{ }^{\circ} \mathrm{C}$ Dark & & 1280 & 1279 & 944 \\
$-20^{\circ} \mathrm{C}$ Dark & & 830 & 1025 & 1208 \\
\hline
\end{tabular}

Each value is mean of 2 independent analyses. content at $4{ }^{\circ} \mathrm{C}$, while almost all IAA was disappeared at $25^{\circ} \mathrm{C}$. These results indicate that storage of the media without degradation of IAA is possible for a few weeks when they are kept in the dark below $25^{\circ} \mathrm{C}$. By storing at $-20^{\circ} \mathrm{C}$, the solid MS media changed to semisolid liquid when they were transferred to room temperature. However, the IAA in the media was fairly stable at $-20^{\circ} \mathrm{C}$.

The degradation process of IAA is not well understood. It is considered that IAA is transformed by IAA oxidase such as peroxidase into 3-methylene oxyindole which is physiologically inactive in situ(6). In the present study, IAA in the MS medium was mainly degraded by light oxidation. The derivatives from IAA degradation following light treatment were not identified.

In the tissue culture of pine trees, the pulse method is often employed in order to supply plant growth regulators to the explants; explants were immersed in the solution containing plant growth regulators for several hours immediately before inoculation and cultured on the hormone-free medium $(2,9)$. Present results suggest that the shoot apices of Musa planted on MS medium absorb IAA at early stages after inoculation, at most within 8 days, and use it for their morphogenesis and subsequent growth. This may support the usefulness of the pulse method for suppling IAA to Musa explants.

\section{Literature Cited}

1. Banerjee, N. and E. de LAnge. 1985. A tissue culture technique for rapid clonal propagation and storage under minimal growth conditions of Musa (banana and plantain). Plant Cell Rep. $4: 351-354$.

2. Bornman, C. H. and T. C. Vogelman. 1984. Effect of rigidity of gel medium on benzyladenine-induced adventitious bud formation and vitrification in vitro in Picea abies. Physiol. Plant. 61 : 505-512.

3. Choveaux, N. A. and J. Van Staden. 1981. The effect of 1-Naphtaleneacetic acid on the endogenous cytokinin content of aseptically cultured bark segments of Salix babylonica. Plant Cell Physiol. 22 : 1207-1214.

4. DARIMONT, E., Y. GASPAR and M. HofinGER. 1971. Auxin-kinetin interaction on the lentil root growth in relation to indoleacrylic acid metabolism. Z. Pflanzenphysiol. $64: 232$ 
-240 .

5. HARRISON, M. A. and P. B. KAUFMAN. 1984. The role of hormone transport and metabolism in apical dominance in oats. Bot. Gaz. $145: 293-297$.

6. Hinman, R. L. and J. LANG. 1965. Peroxidase-catalyzed oxidation of indole-3-acetic acid. Biochemistry. $4: 144-158$.

7. Murashige, T. and F. Skoog. 1962. A revised medium for rapid growth and bio assay with tabacco tissue cultures. Physiol. Plant. $15: 473-497$.

8. Skoog, F. and C. O. Miller. 1957. Chemical regulation of growth and organ formation in plant tissue culture in vitro. Symp. Soc. Exp. Biol. 11 : 118-131.

9. VOGELMANN, T. C., C. H. BORnMAN and P. NISSEN. 1984. Uptake of benzyladenine in explants of Picea abies and Pinus sylvstris. Physiol. Plant. 61 : 513-517.

\section{Musa の生長点の形態形成に及ぼすIAA の効果と 貯蔵培地中の IAA の分解 \\ 平塚 伸 $^{1} \cdot$ 松島二良 ${ }^{1} \cdot$ 古在豊樹 $^{2} \cdot$ 渡部一郎 ${ }^{2}$ \\ 1 三重大生物資源学部 514 津市上浜町 1515 \\ 2 千葉大園芸学部 271 松戸市松戸 648}

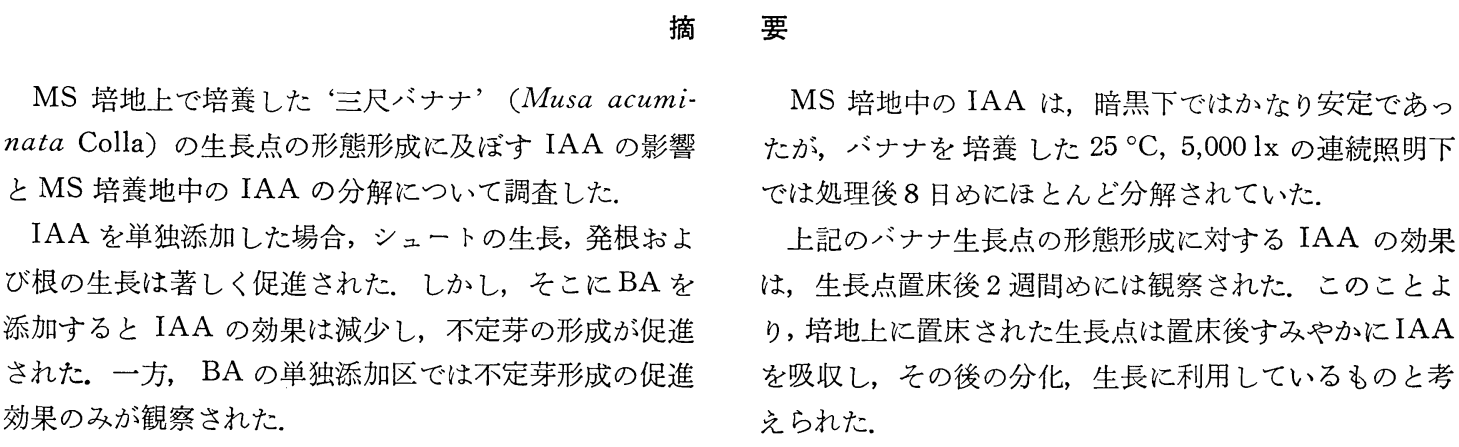

